\title{
SCISSOR-TAILED FLYCATCHER AT EASTEND, SASKATCHEWAN
}

P.M. HOLMES, 1020 12th Street S.E., Salmon Arm, British Columbia. V1E 2C8

At 9:15 a.m. on 13 July 1990 I was travelling east on the Correction line east of Eastend, Saskatchewan and at a point $6 \mathrm{~km}$ e of the junction where the correction line intersects \#13 Highway, I observed a male Scissor-tailed Flycatcher perched on a barbed wire fence, about 25 feet across the ditch from where I was. I stopped immediately and was able to view him for several minutes with my binoculars. He flew westerly for about 40 feet and again landed on the fence. I backed up until I was opposite him and had another good look. This procedure continued five times until he went to a ence line going south and again $\mid$ folowed him four times, each time being able to study him in detail from about 25 eet away. After spending about half an pour with him (I had to meet a deadline) had to leave.
There is absolutely no question as to the identity of this bird. Its long tail, looking like something dragging behind caught my eye, with its hoops of color at the end. It flew down the fence after the fashion of a kingbird, and in general had flycatcherlike behavior. It was longer than a kingbird, and showed rough patches under the wings when in flight. The day was perfectly clear with no wind.

In an effort to establish my credibility, I should mention that I have studied birds all my life - like my father who built a home on 36-6-20-W3rd, and who was well known in ornithological circles in years gone by [See Blue Jay 37(1):9]. I myself collected many specimens for the Saskatchewan provincial museum in the time of Fred Bard who knew our family well.

\section{CHRISTMAS BIRD AND MAMMAL COUNTS - ANNOUNCEMENT}

Count period this year is from Saturday, 15 December 1990 to Wednesday, 2 anuary 1991. Count area should be a circle $24 \mathrm{~km}$ (15 mi.) in diameter. Counts must e a minimum of 3 hours in duration. Count forms will be mailed to compilers who ibmitted counts in 1989. Anyone else wishing to send in a count please write for rms to:

\section{Wayne C. Harris}

Box 414

Raymore, Saskatchewan

SOA $3 J 0$

Reports of counts should be sent to Wayne as soon as possible after they are taken. be included in the report in the March 1991 Blue Jay they must reach Wayne by January 1991. 